Єрмішев О. В., Бацилєва О. В., Шумігай І. В., Кученко Т. А.

УДК 614.7(477):[502.22+504.61](043)

ЛЮДСЬКИЙ ПОТЕНЦАЛ РЕГІОНУ: ПРОБЛЕМИ ВІДТВОРЕННЯ,

ЗБЕРЕЖЕННЯ ТА ВИКОРИСТАННЯ В КОНТЕКСТІ

СТАЛОГО РОЗВИТКУ

О. В. СРМІШЕВ ${ }^{1}$, кандидат біологічних наук, доцент

Email: o.yermishev@donnu.edu.ua

О. В. БАЦИЛСВАํㅛ ${ }^{\mathbf{1}}$, доктор психологічних наук, професор

Email: o.batsileva@donnu.edu.ua

I. В. ШУМІГАЙ${ }^{2}$, кандидат сільськогосподарських наук, старший науковий співробітник

Email: innashum27@gmail.com

Т. А. КУЧЕНКО ${ }^{1}$, асистент кафедри ботаніки та екології

Email: t.odikadze@donnu.edu.ua

1 Донецький національний університет імені Василя Стуса

${ }^{2}$ Інститут агроекології і природокористування НААН

https://doi.org/10.31548/dopovidi2020.06.005

Анотація. Людський потенціал є однією зі складових національного багатства, отже, при формуванні регіональної політики його розвиток має розглядатися як фактор змічнення стійкості території. За оцінкою Світового банку, у розвинених країнах $64 \%$ у структурі національного багатства належить людському капіталу, $16 \%$ - фізичному і тільки $20 \%$ - сировинному фактору. У зв'язку з цим людський капітал та його потенціал віднесений до числа ключових факторів переходу до інноваційного типу розвитку регіону та країни в иілому.

Мета дослідження - виявлення закономірностей змін та тендениій у демографічних прочесах $i$ сочіально обумовленій захворюваності населення Вінницької області, їх основних причин та можливостей покращення ситуачії.

Матеріали і методи дослідження. Використано методи дослідження: бібліосемантичний, системного аналізу, ретроспективного аналізу здоров'я населення в динаміџі за демографічними показниками; захворюваністю за окремими класами хвороб; медичної статистики.

Результати. В останні роки в Україні погіршилась проблема депопуляції неухильного скорочення населення. Основним фактором формування демографічних прочесів є суспільне здоров'я, від його рівня в значній мірі залежить розвиток таких прочесів, як смертність і народжуваність, а також тривалість майбутнього життя. Таким чином, здоров'я нацї визначає чисельність $i$ якість людських ресурсів не тільки в сьогоденні, але $i$ в майбутньому. $У$ статті висвітлено основні проблеми формування народонаселення Вінницької області України: інтенсифікація смертності, надсмертність чоловіків, негативний природний приріст, зниження сумарного коефрічієнту народжуваності, високий рівень демографічної старості. Чисельність населення Вінницької області зменшилась за роки незалежності на 
Єрмішев О. В., Бацилєва О. В., Шумігай І. В., Кученко Т. А.

$16,9 \%$ (України - на 18,1\%). Загальний коефріцієнт народжуваності знизився на 30,9\%, загальний коефіuуієнт смертності підвищчився на 33,0 \%, щзо привело до негативного природного приросту і депопулячії. Основними причинами смерті у 2019 р. стали хвороби органів кровообігу - 67,8 \%; новоутворення - 14,6 \%; травми, отруєння та інші наслідки зовнішніх факторів - 5,7\%. Незважаючи на зниження показника смертності дітей до 1 року у 2 рази, чисельність дитячого населення в області зменшилася більш ніж на 100 тис. осіб. Населення похилого віку збільшилося до 300 \%, шуо привело до регресивного типу вікової структури. Середня очікувана тривалість життя значно відстає (на 10 і більше років) від країн Західної Свропи. Надані пропозищії щзодо можливостей покращення демографічної ситуації $i$ профілактики захворювань, щ⿻о приводять до найбільшого числа смертей.

Висновки $i$ перспективи. Оцінюючи реальні можливості розвитку людського потенціалу в майбутньому на прикладі Вінницької області, можна побачити, щуо значне погіршення всіх основних медико-демографічних показників, яке сталося за останні роки ставить значні обмеження достатності людських ресурсів для подальшого стійкого розвитку області $i$ України в иілому. Демографічні показники народонаселення України свідчать про глибоку демографічну кризу, внаслідок якої чисельність населення за роки незалежності зменшилася на 9,7 млн осіб, у Вінниџькій області - на 667 тис. $C$ ичілий ряд об’єктивних передумов для подальшої депопуляиії, омолодження показників смертності від більшості хвороб, високого рівня демографічної старості тощзо. Необхідно розробити нову довгострокову цільову комплексну міжгалузеву програму “Здоров'я нації”, основним розділом якої повинні стати заходи з подолання демографічної кризи, які б охоплювали не тільки питання простого відтворення населення, але $і$ його розвитку у иирокому сочіальному контексті. У иільову програму повинні бути включені иілі сталого розвитку ООН (ЦСР) і забезпечено контроль за їх виконанням на найвищзму рівні.

Ключові слова: зниження народжуваності, зростання смертності, негативний природний приріст, демографічне старіння

\section{Актуальність. Людський}

потенціал $є$ однією зі складових національного багатства, отже, при формуванні регіональної політики його розвиток має розглядатися як фактор зміцнення стійкості території. Проведений авторами аналіз показує, що тенденції розвитку людського капіталу ведуть до зниження стійкості регіону, про що свідчать старіння населення, зниження якості трудового потенціалу, розвиток негативних міграційних процесів i перш за все його інтелектуальних характеристик i капіталу здоров'я. Існує багато підходів до визначення поняття «здоров’я», але єдиного критерію оцінки громадського здоров'я немає. $\mathrm{y}$ світі використовують комплексний підхід до визначення здоров'я населення, який демографічними захворюваністю, характеризується показниками: фізичним 
Єрмішев О. В., Бацилєва О. В., Шумігай І. В., Кученко Т. А.

розвитком, інвалідністю, донозологічними станами. В даній статті нами розкриті демографічні показники i захворюваність, що призводить до найвищих рівнів смертності.

Аналіз останніх досліджень та публікацій. Як показує світова практика, забезпечення сталого розвитку регіону та країни в цілому не представляється можливим без примноження людського потенціал та його потенціалу. Його значення в умовах модернізації всіх сторін суспільного життя неухильно зростає. За оцінкою Світового банку, в розвинених країнах 64 \% у структурі національного багатства належить людському капіталу, $16 \%$ фізичному і тільки $20 \%$ сировинному фактору.

У зв'язку з цим людський капітал та його потенціал віднесений до числа ключових факторів переходу до інноваційного типу розвитку регіону та країни в цілому.

Серед окремих індикаторів людського розвитку в Україні слід відзначити видатки зведеного бюджету на охорону здоров'я у відсотках до ВВП, які протягом усіх років незалежності не перевищували 4,8 \% і склали у 2020 році 3,6 \%. В останні роки вдалося підвищувати загальну суму видатків на охорону здоров'я переважно за рахунок місцевих бюджетів до 10-13 \%, у 2020 році - до 13,0\% [5].
У другій половині ХХ ст., аж до початку 90-х років, чисельність населення України постійно зростала. Однак інтенсивність цього зростання почала знижуватися вже на початку 1970-х. Вперше смертність перевищила народжуваність у 1991 р. i країна вступила на новий етап розвитку - депопуляцію. Загальний коефіцієнт смертності українців з 12,9 на тисячу населення у 1991 році збільшився до 14,1 у 2019 р. Загальний коефіцієнт народжуваності, навпаки, знизився 3 12,1 до 10,2 \%о $[3,4]$.

Реалізація

Міжгалузевої комплексної програми «Здоров’я нації» та комплексу регіональних i відомчих програм у сфері охорони й поліпшенні здоров'я населення сприяла суттєвому гальмуванню поглиблення медико-демографічної кризи, але не забезпечила іiі подолання [4, 11].

Якщо у 1990 р. чисельність населення України становила понад 52 млн осіб, то 1 червня 2020 року в Україні проживало 41 млн 785 тис. осіб [3], що на 21,15 \% менше.

Секретаріат ООН опублікував чергову доповідь про світові демографічні тенденції. Незважаючи на збереження тенденції до зниження народжуваності в розвинених країнах, очікується приріст населення нашої планети у 2050 р. до 9 млрд осіб. Очікувана тривалість життя в Європі складає понад 79 років для жінок і 70,5 - для чоловіків. До 2050 
Єрмішев О. В., Бацилєва О. В., Шумігай І. В., Кученко Т. А.

p. 2 млрд жителів планети будуть старіше за 60 років [9]. Прогноз для України несприятливий: до зазначеного часу очікується скорочення 1ї населення ще на 7,8 млн осіб $[7,11]$.

Стан репродуктивного здоров'я характеризують показники народжуваності i ті показники здоров'я жінок і дітей, інтегрованим відображенням яких $\epsilon$ материнська i дитяча смертність. I хоча намітилася тенденція до їх зниження, рівень материнської смертності залишається одним 3 найвищих в Свропі. Одним 3 визначальних чинників $\epsilon$ аборти, які залишаються поширеним методом регуляції народжуваності українських жінок. Кількість абортів в 1-2 рази перевищує кількість пологів (у Франції та Німеччині цей показник дорівнює 0,25, в Японії 0,06). Негативними наслідками абортів $\epsilon$ також безпліддя, невиношуваність вагітності. У 5 випадках iз 10 тис. абортів реєструється летальний результат [1, 4].

Смертність за віковим складом померлих характеризується високим рівнем смерті немовлят i населення працездатного віку [14]. Особливість рівня смертності в Україні полягає не тільки в тому, що люди взагалі вмирають від серцево-судинних захворювань, а в тому, що серед померлих від цих хвороб надто багато осіб молодого віку, особливо чоловіків. Різкі відмінності від західного і східноєвропейського стандарту у чоловіків проявляються вже у віці 25-29 років і потім стрімко зростають - «зверхсмертність чоловіків» $[4,8]$.

Проблема України полягає також у зниженні середніх вікових показників причин смертності від більшості хвороб: диференціація між причинами смерті і середнім віком смерті дуже висока (на відміну від країн (С). Найнижчий середній вік смерті серед українців реєструється по класу інфекційних хвороб (СНІД, туберкульоз) [4].

Зменшилась

очікувана тривалість життя українців, яка становить 71 рік (66 років - чоловіки, 75 - жінки). За цим показником Україна займає 52-ге місце серед країн світу [4].

Всесвітня організація охорони здоров'я B

глобальному стратегічному документі для національних служб охорони здоров’я «Здоров’я для всіх у XXI столітті» визначила критерії, до яких повинні прагнути всі країни.

\section{Серед цих критеріїв} позитивний природний приріст населення і середня тривалість життя, яка повинна бути не менше ніж 75 років.

3 огляду на те, що демографічна ситуація в Україні в даний час не відповідає зазначеним критеріям, проблема вивчення соціальнодемографічних процесів $\epsilon$ досить актуальною. 
Єрмішев О. В., Бацилєва О. В., Шумігай І. В., Кученко Т. А.

Мета дослідження - виявлення закономірностей змін та тенденцій у демографічних процесах і соціально обумовленій

захворюваності

населення Вінницької області, їх основних причин та можливостей покращення ситуації.

\section{Матеріали} дослідження.

\section{i}

методи

Матеріалами дослідження стали вітчизняні та світові наукові джерела, щорічні збірники статистичних даних Вінницької області та України в цілому 3 демографічного розвитку i захворюваності населення; щорічні доповіді керівництва країни та MO3 із цих питань, інформації регіонального бюро ВОО3; законодавчі документи.

Використано

методи

дослідження: бібліосемантичний, системного аналізу, ретроспективного аналізу здоров'я населення в динаміці за демографічними показниками (народжуваності, смертності, природного приросту, середньої очікуваної тривалості життя, дитячої смертності); захворюваністю за окремими класами хвороб, що призводять до найбільшої питомої ваги випадків смерті; медичної статистики: відносні величини, динамічні ряди, оцінка тенденцій демографічних показників, захворюваності, графічне зображення статистичних даних, комп'ютерні технологї.

Результати дослідження та їх обговорення. Розвиток людського капіталу народонаселення, кількісний і якісний потенціал його відтворення $\epsilon$ умовою, основою і метою сталого розвитку суспільства i держави. Державна політика у галузі суспільного буття повинна бути акцентована в першу чергу на вирішення найбільш актуальних, пріоритетних завдань. В останні роки в Україні в їх число ввійшла проблема депопуляції неухильного скорочення населення. Основним фактором формування демографічних процесів є суспільне здоров'я, від його рівня в значній мірі залежить розвиток таких процесів, як смертність і народжуваність, а також тривалість майбутнього життя. Таким чином, здоров'я нації визначає чисельність i якість людських ресурсів не тільки в сьогоденні, але $\mathrm{i}$ в майбутньому. Популяція, володіючи певним життєвим i трудовим потенціалом, втрачає його на кожному етапі розвитку поколінь через травми, хвороб, переривання вагітності, мертвонароджуваності, передчасної смертності тощо.

Несприятлива

соціальнодемографічна ситуація склалася i y Вінницькій області, яка має самобутню історію, великий економічний, виробничий, кадровий потенціал, багаті природні ресурси, вигідне економічне положення. Все це сприяло бурхливому аграрному, промисловому, економічному та соціальному розвитку регіону, починаючи 3 кінця XIX ст. i до 
Єрмішев О. В., Бацилєва О. В., Шумігай І. В., Кученко Т. А.

теперішнього часу. Однак інтенсивний

розвиток агровиробництва i промисловості створює в області напружену екологічну та демографічну ситуацію, що ставить, поряд з іншими, завдання вдосконалення медико-санітарної допомоги та соціального обслуговування населення [4].

Станом на 1 січня 2020 року загальна чисельність наявного населення області становила 1545,4 тис. осіб, що на 18,22 \% менше, ніж на початок 1995 року. Найбільшу чисельність жителів регіону було досягнуто у 1995 році - 1889,7 тис., потім відзначено щорічне зменшення на близько 14,5 тис. осіб. Населення, яке постійно проживає, склало 1545,4 тис. осіб (зменшилося за цей період також на 18,22 \%). Міське населення склало 51,73 \%, сільське $-48,2 \%$, що значно відрізняється від даних двадцятип'ятирічної давності $(47,09 \%$ i 52,91 \% відповідно) і свідчить про стійку урбанізацію. Чисельність міського населення при цьому зменшилася на 10,16 \%, сільського - на 25,39 \% [13].

Співвідношення міського i сільського населення в Вінницькій області значно відрізняється від таких показників в Україні, де питома вага сільського населення стабільно становить 30-32 \% [3]. Чоловіче населення складає 46,33\%, жіноче 53,67 \% (у 1995 р. було відповідно 45,19 i $54,81 \%$ ), тобто триває невелике зменшення чоловіків, на 1000 жінок припадає 842 чоловіки (таблиця).

Динаміка чисельності наявного і постійного населення Вінницької області за 1995-2019 рр. (станом на 1 січня, тис. осіб) (побудовано за даними [13])

\begin{tabular}{|c|c|c|c|c|c|c|c|c|c|c|}
\hline \multirow[t]{2}{*}{ Рік } & \multirow{2}{*}{$\begin{array}{c}\text { Зага } \\
\text { льна } \\
\text { чисельн } \\
\text { ість }\end{array}$} & \multicolumn{9}{|c|}{ Чисельність постійного населення } \\
\hline & & $\begin{array}{l}\text { Всьог } \\
\text { о }\end{array}$ & $\begin{array}{c}\text { Міськ } \\
\text { e }\end{array}$ & $\%$ & $\begin{array}{c}\text { Сільськ } \\
\text { e }\end{array}$ & $\%$ & $\begin{array}{c}\text { чоловік } \\
\text { и }\end{array}$ & $\%$ & жінки & $\%$ \\
\hline 1995 & 1889,7 & $\begin{array}{c}1875, \\
6\end{array}$ & 889,8 & 47,4 & 999,9 & 53,3 & 847,6 & 45,2 & $\begin{array}{c}1028, \\
0\end{array}$ & 54,8 \\
\hline 2000 & 1811,0 & $\begin{array}{c}1797, \\
1\end{array}$ & 844,3 & 46,9 & 966,7 & 53,8 & 818,4 & 45,5 & 978,7 & 54,5 \\
\hline 2005 & 1720,1 & $\begin{array}{c}1713, \\
1\end{array}$ & 813,1 & 47,5 & 907,0 & 52,9 & 783,1 & 45,7 & 930,0 & 54,3 \\
\hline 2010 & 1650,6 & $\begin{array}{c}1643, \\
5\end{array}$ & 814,2 & 49,5 & 836,4 & 50,9 & 752,6 & 45,8 & 890,9 & 54,2 \\
\hline 2014 & 1618,3 & $\begin{array}{c}1611, \\
2\end{array}$ & 815,3 & 50,6 & 803,0 & 49,8 & 742,2 & 46,1 & 869,0 & 53,9 \\
\hline 2015 & 1610,6 & $\begin{array}{c}1603, \\
5\end{array}$ & 814,8 & 50,8 & 795,8 & 49,6 & 739,6 & 46,1 & 863,9 & 53,9 \\
\hline 2017 & 1590,4 & $\begin{array}{c}1583, \\
3\end{array}$ & 810,1 & 51,2 & 780,3 & 49,3 & 731,8 & 46,2 & 851,5 & 53,8 \\
\hline
\end{tabular}


Срмішев О. В., Бацилєва О. В., Шумігай І. В., Кученко Т. А.

\begin{tabular}{|c|c|c|c|c|c|c|c|c|c|c|}
\hline 2019 & 1560,4 & $\begin{array}{c}1553, \\
3\end{array}$ & 801,7 & 51,6 & 758,7 & 48,8 & 719,0 & 46,3 & 834,3 & 53,7 \\
\hline $\begin{array}{l}\text { Темп } \\
\text { приросту } \\
2018 / 1990\end{array}$ & $-17,43 \%$ & $\begin{array}{c}-17,18 \\
\%\end{array}$ & $\begin{array}{c}-9,90 \\
\%\end{array}$ & + & $24,12 \%$ & - & $-15,17 \%$ & + & $\begin{array}{c}- \\
17,97 \\
\%\end{array}$ & - \\
\hline
\end{tabular}

Жіноче населення за роки незалежності зменшилось на 19,69 \%, чоловіче на $15,92 \%$.

Чисельність населення м. Вінниця у червні 2020 р. склала 370,7 тис. осіб. В Україні м. Вінниця $є$ дванадцятою за чисельністю населення.

Гендерна структура населення обумовлена, перш за все, різними рівнями смертності серед чоловіків i жінок, сформованими під впливом як біологічних, так i соціальних факторів. На великих популяціях співвідношення числа народжень стабільне: 52,1 \% хлопчиків проти 47,9 \% дівчаток; тому серед дітей переважають хлопчики. У молодому i середньому віці чисельність чоловіків i жінок приблизно однакова, в літньому віці питома вага жінок стає більшою, ніж чоловіків через більш високу смертність останніх [11].

Для вікової структури населення області, як і в цілому по Україні, характерна тенденція старіння населення. Так, за віком найбільша питома вага із загальної чисельності населення Вінницької області припадає на групу 70 років і старше (11,0\% в містах, 14,7 \% в сільській місцевості); 7,29 \% - 25-29 років; 5,69 \% на - 20-24, 6,85\% - на 50-54 роки; по 8,14 \% - на 30-34, 7,01\% - на 45-
49 років [15]. Діти до 1 року становлять $1,3 \%$, серед дорослих найменшу питому вагу займає група 65-69 років $(5,59 \%)$.

Особи

молодшого непрацездатного віку (до 15 років включно) склали 15,19 \%, працездатного (16-59 років) 65,44 \%, старше працездатного (60 i більше років) - 19,37\%.

У 1995 р. це співвідношення було $19,71 \% ; 58,8 \% ; 22,21 \%$, тобто питома вага осіб молодшого віку перевищувала старші вікові групи, що характерно для прогресивного типу вікової структури. У даний час для області, як і в цілому для країни, характерний регресивний тип вікової структури. У середньому, по Вінницькій області на 1000 осіб населення припадає майже 400 пенсіонерів [10].

Нами поглиблено вивчено стан природного руху населення - зміни його чисельності та якісного складу внаслідок основних демографічних явищ: народжуваності i смертності. Загальний коефіцієнт народжуваності в 2019 р. склав по області 1,2 \%о, що на 37,66 \% нижче 1995 p.

Найнижчим коефіцієнт народжуваності був у 2019 р. та 2001 p. $(1,205 ; 1,221 \%$ \%), потім поступово йшло

показника, 
Єрмішев О. В., Бацилєва О. В., Шумігай І. В., Кученко Т. А.

досягнувши в 2012 р. 1,589 \% і знову пішло на спад.

Загальний коефіцієнт смертності склав у 2019 р. 15,61 \%о, що на 9,29 \% вище, ніж у 1990 р. $(17,22)$. Найвищим коефіцієнт смертності був у період 2005-2008 рр. (від 17,0 до 17,7\%о).

Природний приріст населення, що становив у 1995 р. -12562 осіб, у 2019 р. природне скорочення склало 12254 осіб [13].

У порівнянні 31995 р. $(1,634)$ сумарний коефіцієнт народжуваності знизився до 1,205 (на 26,25 \%). На 1000 жінок відповідної вікової групи за ці роки відбулося, поряд зі зниження, зміщення найвищого коефіцієнту народжуваності 3 20-24 років на 25-29 років [2].

За роки незалежності чисельність дитячого населення в області зменшилася більш, ніж на 100 тис. осіб. Зростає чисельність дітей, народжених поза шлюбом або в неповних сім'ях. Серед молоді поширюються неформальні сімейні стосунки, що також негативно впливає на розвиток демографічних процесів. Питома вага дітей, народжених жінками, які не перебувають у зареєстрованому шлюбі, збільшилася в 1,7 рази і склала по області в 2019 р. 16,6 \%. Кількість зареєстрованих шлюбів зменшилася на 26,83 \% (3 8,8 до 6,0 на 1000 населення).

Найменше шлюбів було укладено в 2004 та 2018 рр. (5,7\%о) Кількість зареєстрованих розлучень

збільшилось (з 3,2 до 3,6). Найбільше розлучень було в 2011 та 2018 рр. по 4,0\% [13].

За даними вибіркового обстеження умов життя домогосподарств, яких в області налічується 629,7 тис., 52,3 \% знаходяться в міських поселеннях (дві третини - у великих містах). Середня кількість людей в сім’ї - 2,47 осіб. 33,0 \% всіх сімей складається 3 двох осіб, 25,4 \% - 3 трьох, 17,1 \% - 3 чотирьох і більше, 24,5 \% - 3 однієї людини. Більше третини домогосподарств мають дітей до 18 років. У більшості 3 них (71,5 \%) тільки одна дитина, в 25,6 \% сімей дві дитини, більше двох дітей - у 2,9 \% сімей [10]. У результаті розлучень щороку опиняються в неповних сім'ях більше 5 тис. дітей. Найбільше розлучень відбувається через 1-4 роки перебування в шлюбі (30,3 \%) і 5-9 років $(24,2 \%)$.

Слід зазначити все ж, що на тлі триваючого збільшення кількості розлучень в цілому по країні в Вінницькій області намітилася тенденція до поліпшення цього показника. Крім того, в 2,2 рази зменшилася кількість абортів у жінок фертильного віку, знизився коефіцієнт відношення абортів до пологів в 2000 році на 100 вагітностей було 96 абортів, на 2019 рік цей показник змінився i на 100 вагітностей було 34 аборти [13, 18$]$.

Одним

3

демографічних важливих показників 
Срмішев О. В., Бацилєва О. В., Шумігай І. В., Кученко Т. А.

громадського здоров’я населення $\epsilon$ вікової групи 70 років і старше, смертність, яка характеризує поширеність найбільш важкої i небезпечної для життя патології. Коефіцієнти смертності населення області за віком знизилися по 5 вікових групах до 24 років, в той же час відзначено їхній значний ріст по 9 починаючи 32007 р., відзначено зниження коефіцієнта смертності, що пов'язано, в основному, з сучасними досягненнями геріатричної медицини. На кожну тисячу чоловіків помирає 16 осіб за рік, на 1000 жінок $-14[3,13]$.

вікових групах від 25 до 69 років. За

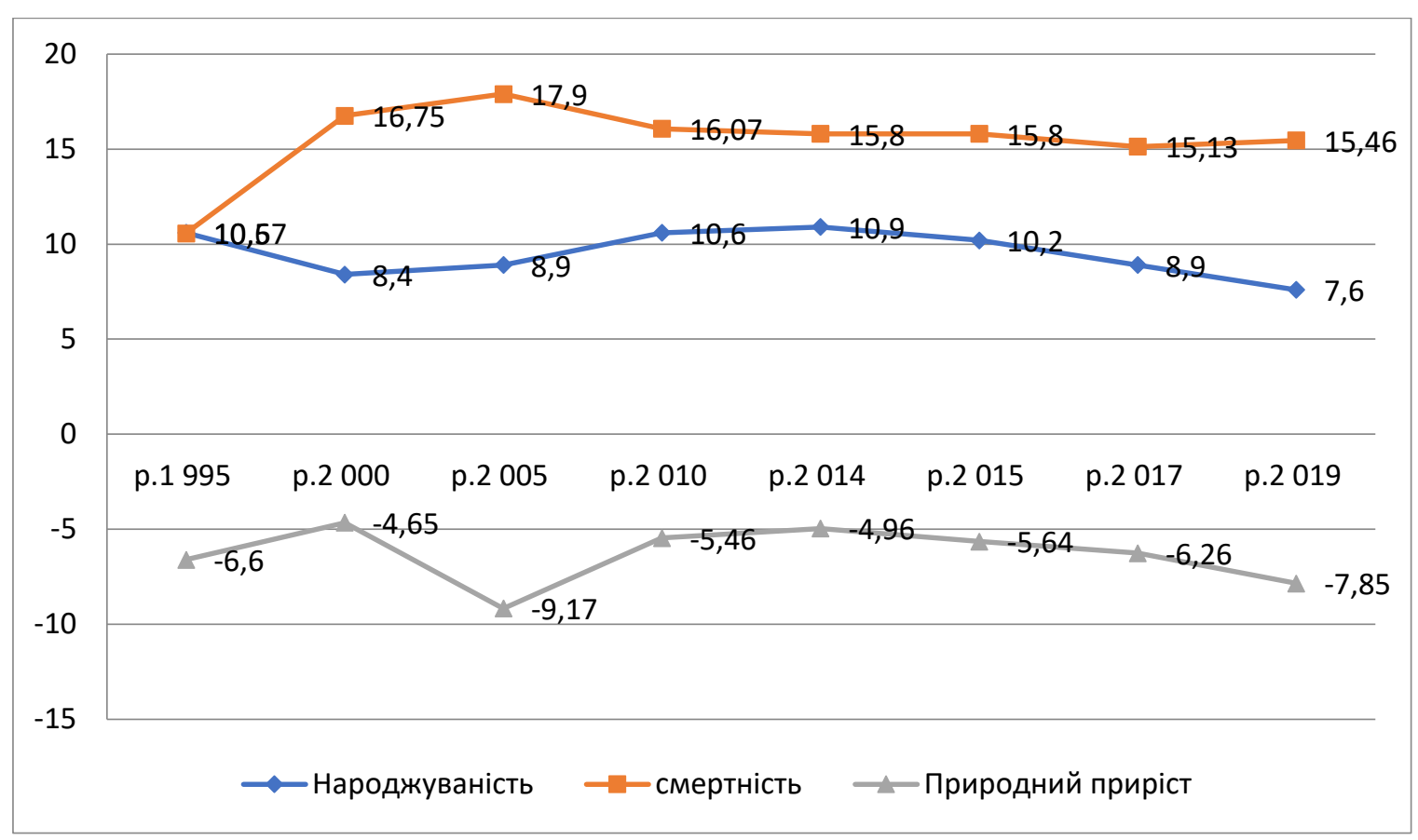

Рис. Коефіціснти народжуваності, смертності та природного приросту населення Вінницької області у 1995-2019 рр. на 1000 осіб (побудовано за даними [13]).

Основними причинами смерті е 2019 році стали: I рангове місце хвороби органів кровообігу $-66,02 \%$ 3 тенденцією до незначного зниження, II місце - новоутворення 14,71\%, III місце - зовнішні причини - 7,02 \%, IV місце захворювання органів дихання $5,01 \%, \mathrm{~V}$ місце - хвороби органів травлення - 5,01\% 3 тенденцією до зростання, VI місце - деякі інфекційні та паразитарні хвороби - 1,16\% 3 тенденцією до зростання. До 2007 року включно хвороби органів дихання посідали п'яте рангове місце, як і в цілому по Україні, проте з 2008 p. в Вінницькій області це місце посіли деякі інфекційні хвороби: СНІД склав 29,06 \%, туберкульоз $58,12 \%$ від усіх випадків смерті в цьому класі. На інші причини смерті припадає лише $3,5 \%[6,13]$. 
Єрмішев О. В., Бацилєва О. В., Шумігай І. В., Кученко Т. А.

$$
\text { У Вінницькій області }
$$

простежується тенденція зниження показника смертності дітей до 1 року (за роки незалежності - майже в 8 разів), в 2019 році він склав 2,11\%, що свідчить як про поліпшення медичного спостереження за вагітними жінками, так i про підвищення ефективності диспансеризації новонароджених, зокрема створення перинатальних центрів. У структурі малюкової смертності перше місце посідають патологічні стани, що виникають у перинатальному періоді, друге вроджені дефекти розвитку, деформації та хромосомні аномалї, третє - хвороби нервової системи, четверте - органів дихання, п'яте нещасні випадки та інші зовнішні причини смерті $[6,13]$.

Одним 3 демографічних показників, які використовуються в світовій практиці для інтегральної оцінки стану здоров'я населення, є середня очікувана тривалість життя. Аналіз цього показника 31990 p. свідчить про те, що він скорочувався до 1997-1999 рр., потім почав збільшуватися, досягнувши вихідних цифр (71,76 роки), хоча все ж продовжує значно відставати (на 10 i більше років) від країн Західної Європи і на $2 \%$ - від середнього рівня по Україні. Крім того, залишається великим розрив у рівнях чоловічої $\mathrm{i}$ жіночої тривалості життя - 10,03 років [2].
3 позитивного можна відзначити, що виробничий травматизм в області знизився за роки незалежності в 5 разів; в т.ч. зі смертельними наслідками - в 2 рази; первинний вихід на інвалідність - в 1,3 рази. Збільшилася кількість місць в будинках-інтернатах для інвалідів i громадян похилого віку.

У питаннях сімейної політики та народжуваності основною метою $\epsilon$ формування системи особистих i суспільних цінностей, орієнтованих на створення сім'ї 3 двома-трьома дітьми, зміцнення та підвищення піi виховного потенціалу як основного осередку відтворення населення. Об'єктами безпосередньої уваги держави повинні бути молоді сім’ї та сім’ї з дітьми. У сфері поліпшення здоров'я, зниження смертності та підвищення тривалості життя населення необхідні заходи 3 покращення якості життя, профілактики шкідливих i небезпечних виробничих чинників, поліпшення санітарно-епідемічної та екологічної ситуації, стимулювання позитивних зрушень у поведінці та способі життя людей $[4,10]$.

Протягом багатьох років спостерігається найвищий рівень смертності від хвороб системи кровообігу в структурі причин смерті, що потребує, зокрема, створення не тільки в обласних центрах, а i в більшості міст кардіохірургічних закладів, для доведення кількості кардіохірургічних втручань типу 
Єрмішев О. В., Бацилєва О. В., Шумігай І. В., Кученко Т. А.

стентування, шунтування до рівня світових стандартів. Це допоможе суттєво знизити кількість інсультів, інфарктів мікарду та інших судинних патологій, наразі у м. Вінниця до кінця 2020 року планується введення в експлуатацію нового корпусу регіонального кардіоцентру.

Необхідно значно розширити систему первинної профілактики виникнення хвороб системи кровообігу. Стратегія боротьби зі смертністю від цих хвороб повинна відрізнятися для осіб різного віку. У молодих чоловіків високий рівень смертності від серцево-судинних захворювань дуже часто асоціюється 3 курінням, зловживанням алкоголем, іншими наркотичними речовинами i взагалі тісніше пов'язаний зі способом життя, ніж коли йдеться про людей похилого віку, в яких головний внесок у розвиток хвороби роблять природні вікові зміни [4, 8, 9]. Численні світові дослідження даних щодо регулярного проходження періодичних профілактичних оглядів безсимптомними особами у віці до 65 років не знижують смертність. Доведено, що цільовий профілактичний скринінг на конкретні захворювання 3 урахуванням статі, віку, факторів ризику дає значно більш ефективні результати до зниження цих захворювань. Зокрема у 2016 р. надані Європейські рекомендації 3 профілактики хвороб системи кровообігу щодо звуження вікового інтервалу для проведення скринінгу $[12,16]$.

31 січня 2016 р. набрала чинності стратегія ООН, в якій поставлені цілі сталого розвитку (ЦСР). Це 17 цілей і 1693 задачі, які держави-члени $\mathrm{OOH}$ погодились досягти до 2030 p. Всі ЦСР безпосередньо пов'язані зі здоров'ям або впливають на політику охорони здоров'я: ЦСР-3 закликає “забезпечити здоровий спосіб життя $\mathrm{i}$ сприяти благополуччю всіх у будьякому віці"; ЦСР-3.4 передбачає скорочення передчасної смертності від неінфекційних захворювань (НI3) на одну третину до 2030 р. [17].

Демографічні проблеми потребують розробки сучасної ідеології демографічного розвитку України, підвищення якості наукових розробок у галузі демографічних досліджень, їх фінансову підтримку. Це має бути основним змістом демографічної стратегіï держави сьогодні.

\section{Висновки i перспективи.} Демографічні показники населення України свідчать про глибоку демографічну кризу, внаслідок якої чисельність населення за роки незалежності зменшилася на 9,7 млн осіб, у Вінницькій області - на 344,4 тис. $€$ цілий ряд об'єктивних передумов для подальшої депопуляції, омолодження показників смертності від більшості хвороб, 
Єрмішев О. В., Бацилєва О. В., Шумігай І. В., Кученко Т. А.

високого рівня демографічної старості тощо.

У Вінницькій області існують аналогічні проблеми, які посилюються надсмертністю чоловіків, зниженням сумарного коефіцієнта народжуваності, зменшенням кількості зареєстрованих шлюбів, зростанням числа дітей-сиріт та дітей, батьки яких позбавлені батьківських прав. Зареєстровані високі рівні наркоманії та токсикоманії, ВІЛ/СНІДу, суїцидів, психічних і венеричних захворювань.

Для відновлення режиму відтворення населення i підвищення тривалості активного життя поряд iз впровадженням сучасних медичних технологій лікування захворювань необхідні посилення профілактичної спрямованості системи охорони здоров'я, а також орієнтація всіх сфер життєдіяльності на оздоровлення умов праці побуту, відмову від шкідливих звичок з метою створення суспільного середовища, сприятливого для вибору і засвоєння моделі поведінки, спрямованої на

\section{Список використаних джерел}

1. Афанасьєва Ю. В. Чинники дисфункції сучасної української сім'ї як об’єкта державної демографічної політики. Актуальні проблеми державного управління. 2014. №1. С. 309-316.

2. Статистична інформація Державної служби статистики України. Інститут демографії та соціальних досліджень імені М.В. Птухи НАН України. URL: http://database.ukrcensus.gov.ua/

3. Демографическая ситуация в Украине. URL: http://www.unian.net.

4. Єрошкіна Т. В., Дерев'янко Д. В. Основні показники стану здоров'я здоровий спосіб життя. Практична реалізація заходів державної політики у сфері охорони здоров'я населення стане можливою завдяки масштабним цільовим програмам, дотацій 3 бюджету і місцевих ресурсів.

Необхідно розробити нову довгострокову цільову комплексну міжгалузеву програму “Здоров’я нації, основним розділом якої повинні стати заходи 3 подолання демографічної кризи, які б охоплювали не тільки питання простого відтворення населення, але i його розвитку у широкому соціальному контексті. В цільову програму повинні бути включені цілі сталого розвитку ООН і забезпечено контроль за їх виконанням на найвищому рівні.

Перспективи

подальших

досліджень У пдальших дослідженнях необхідно продовжувати соціально-гігієнічний моніторинг за станом здоров'я населення і надати пропозиції щодо участі у розробці цільової програми “Здоров’я націі” на рівні регіону.

населення промислового регіону України за роки незалежності. Україна. Здоров'я наиії. 2019. № 1 (54). С. 7-14.

5. Заклади охорони здоров'я та захворюваність населення України у 2017 р.: статистичний збірник. К. : Держслужба статистики України, 2018. URL: http://www.ukrstat.gov.ua.

6. Захист дітей, які потребують особливої уваги суспільства: Статистичний збірник. К. : Державна служба статистики України, 2014. 79 с.

7. Либанова Э. М. Демографические сдвиги в контексте социального развития. 
Єрмішев О. В., Бацилєва О. В., Шумігай І. В., Кученко Т. А.

Демографія та соиіальна економіка. 2014. № 1. C. 9-23.

8. Маркович I. I. Вплив медикодемографічних показників на реформування медичної галузі як складової системи безпеки України. Україна. Здоров'я наџіiї. 2013. № 4 (28). C. 29-34.

9. Мировые демографические тенденции. Женева: Экономический и Социальный Совет ООН, 2011. 35 с.

10. Палієнко О. А. Демографічна криза в Україні: шляхи їі подолання. Young Scientist. 2017. № 9,1 (49,1). C. 133-136.

11. Позняк О. В., Шевчук П. Є. Демографічні перспективи України до 2060 року. Демографія та соиіальна економіка. 2014. № 1. С. 72-84.

12. Порівняльний аналіз підходів до профілактики в Європі та Україні / В. М. Лехан та ін. Украӥна. Здоров’я нащії. 2017. № 3 (44). С. 159-165.

13. Статистична

Головного управління статистики у Вінницькій області за 2019 рік // https://www.vn.ukrstat.gov.ua/.

14. Чепелевська Л. А. Тенденції медико-демографічних показників України у XXI столітті. Украӥна. Здоров'я нації. 2018. № 1 (47). C. 48-52.

15. Щорічна доповідь про стан здоров'я населення, санітарно-епідемічну ситуацію та результати діяльності системи охорони здоров'я України. 2016 рік / МO3 України, ДУ «УІСД МОЗ України». К., 2017. 516 с.

16. European Guidelines on cardiovascular disease prevention in clinical practice. 2016 / M. F. Piepoli et al. European Heart Journal. 2016. № 37 (29). P. 2315-2381.

17. Poston D. L., L. F. Bouvier. Population and society: an introduction to demography. 2nd edition. New York: Cambridge University Press. 2017. 532 p.

18. Новини Вінниці 20 хвилин. Своє право на аборт використовує кожна четверта вагітна. URL: https://vn.20minut.ua/vona-i vinnicya/.

\section{References}

1. Afanasieva, Yu. V. (2014). Chynnyky dysfunktsii suchasnoi ukrainskoi simi yak obiekta derzhavnoi demohrafichnoi polityky [Factors of dysfunction of the modern
Ukrainian family as an object of state demographic policy]. Aktualni problemy derzhavnoho upravlinnia - Pressing Problems of Public Administration, 1, 309-316 [in Ukraine].

2. Statystychna informatsiia Derzhavnoi sluzhby statystyky Ukrainy. Instytut demohrafii ta sotsialnykh doslidzhen imeni M.V. Ptukhy NAN Ukrainy [Statistical information of the State Statistics Service of Ukraine. Ptoukha Institute for Demography and Social Studies of the National Academy of Sciences of Ukraine]. (n.d.) database.ukrcensus.gov.ua. Retrieved from http://database.ukrcensus.gov.ua/ [in Ukraine].

3. Demograficheskaia situatsiia $\mathrm{v}$ Ukraine [Demographic situation in Ukraine]. (n.d.) www.unian.net. Retrieved from http://www.unian.net [in Russian].

4. Ieroshkina, T. V., Derevianko, D. V. (2019). Osnovni pokaznyky stanu zdorovia naselennia promyslovoho rehionu Ukrainy za roky nezalezhnosti [The main indicators of the state of health of the population of the industrial region of Ukraine during the years of independence]. Ukraina. Zdorovia natsii Ukraine. The health of the nation, 1 (54), 7-14. [in Ukraine].

5. Zaklady okhorony zdorovia ta zakhvoriuvanist naselennia Ukrainy u 2017 r.: statystychnyi zbirnyk. Derzhsluzhba statystyky Ukrainy, 2018 [Health care facilities and morbidity of the population of Ukraine in 2017: a statistical collection. State Statistics Service of Ukraine], 2018. (n.d.) www.ukrstat.gov.ua. Retrieved from http://www.ukrstat.gov.ua [in Ukraine].

6. Zakhyst ditei, yaki potrebuiut osoblyvoi uvahy suspilstva: Statystychnyi zbirnyk [Protection of children in need of special attention of society: Statistical collection]. (2014). Kyiv: Derzhavna sluzhba statystyky Ukrainy [in Ukraine].

7. Lybanova, E. M. (2014). Demohrafycheskye sdvyhy v kontekste sotsyalnoho razvytyia [Demographic shifts in social development context]. Demohrafiia ta sotsialna ekonomika - Demography and social economy, 1, 9-23 [in Russian].

8. Markovych, I. I. (2013). Vplyv medyko-demohrafichnykh pokaznykiv na reformuvannia medychnoi haluzi yak skladovoi 
Єрмішев О. В., Бацилєва О. В., Шумігай І. В., Кученко Т. А.

systemy bezpeky Ukrainy [The impact of medical and demographic indicators on the reform of the medical sector as a component of Ukraine's security system]. Ukraina. Zdorovia natsii - Ukraine. The health of the nation, 4 (28), 29-34 [in Ukraine].

9. Mirovye demograficheskie tendentsii [World demographic trends]. (2011). Zheneva: Ekonomicheskii i Sotsialnyi Sovet OON - Geneva: United Nations Economic and Social Council [in Russian].

10. Paliienko, O. A. (2017). Demohrafichna kryza v Ukraini: shliakhy yii podolannia [Demographic crisis in Ukraine: ways of its extension]. Young Scientist, 9,1 $(49,1), 133-136$ [in Ukraine].

11. Pozniak, O. V., Shevchuk, P. Ye. (2014). Demohrafichni perspektyvy Ukrainy do 2060 roku [Popuiation prospects of Ukraine up to 2060.]. Demohrafiia ta sotsialna ekonomika - Demography and social economy, 1, 72-84 [in Ukraine].

12. Lekhan, V. M., Kriachkova, L.V., Maksymenko, O.P., Zaiarskyi, M.I., Brodska, E.V. (2017). Porivnialnyi analiz pidkhodiv do profilaktyky $\mathrm{v}$ Yevropi ta Ukraini [Comparative analysis of approaches to prevention in Europe and Ukraine]. Ukraina. Zdorovia natsii - Ukraine. The health of the nation, 3 (44), 159-165 [in Ukraine].

13. Statystychna informatsiia Holovnoho upravlinnia statystyky u Vinnytskii oblasti za 2019 rik [Statistical information of the Main Department of Statistics in Vinnytsia region for 2019] (n.d.) vn.ukrstat.gov.ua. Retrieved from https://www.vn.ukrstat.gov.ua/ [in Ukraine].
14. Chepelevska, L. A. (2018). Tendentsii medyko-demohrafichnykh pokaznykiv Ukrainy u XXI stolitti [Trends in medical and demographic indicators of Ukraine in the XXI century]. Ukraina. Zdorovia natsii Ukraine. The health of the nation, 1 (47), 4852 [in Ukraine].

15. Shchorichna dopovid pro stan zdorovia naselennia, sanitarno-epidemichnu sytuatsiiu ta rezultaty diialnosti systemy okhorony zdorovia Ukrainy. 2016 rik / MOZ Ukrainy, DU «UISD MOZ Ukrainy» [Annual report on the state of health of the population, the sanitary and epidemiological situation and the results of the health care system of Ukraine. 2016 / Ministry of Health of Ukraine]. (2017). Kyiv: MOZ Ukrainy, DU «UISD MOZ Ukrainy» [in Ukraine].

16. Piepoli, M. F., Hoes, A. W., Agewall, S., Albus, C., Brotons, C., Catapano, A. L. et al. (2016). 2016 European Guidelines on cardiovascular disease prevention in clinical practice. European heart journal,37(29), 2315-2381.

https://doi.org/10.1093/eurheartj/ehw106

17. Poston, D. L., Bouvier, L. F. (2017). Population and society: an introduction to demography. 2nd edition. New York: Cambridge University Press.

18. Novyny Vinnytsi 20 khvylyn. Svoie pravo na abort vykorystovuie kozhna chetverta vahitna [News of Vinnytsia 20 minutes. Every fourth pregnant woman exercises her right to an abortion]. (n.d.) vn.20minut.ua/vona-i vinnicya. Retrieved from https://vn.20minut.ua/vona-i vinnicya/ [in Ukraine].

\section{ЧЕЛОВЕЧЕСКИЙ ПОТЕНЦИАЛ РЕГИОНА: ПРОБЛЕМЫ ВОСПРОИЗВЕДЕНИЯ, СОХРАНЕНИЯ И ИСПОЛЬЗОВАНИЯ В КОНТЕКСТЕ УСТОЙЧИВОГО РАЗВИТИЯ

\author{
О. В. Ермишев, О. В. Бацилева, И. В. Шумигай, Т. А. Кученко
}

Аннотация. Человеческий потенциал является одной из составляюших национального богатства, следовательно, при формировании региональной политики его развитие должно рассматриваться как фактор укрепления устойчивости территории. По оченке Всемирного банка, в развитых странах $64 \%$ в структуре национального богатства принадлежит человеческому капиталу, $16 \%$ - физическому и только 20 \% - сырьевому фактору. В связи с 
Єрмішев О. В., Бацилєва О. В., Шумігай І. В., Кученко Т. А.

этим человеческий капитал и его потенцииал отнесен к числу ключевых факторов перехода к инновационному типу развития региона и страны в целом.

Цель исследования - выявление закономерностей изменений и тенденций в демографических прочессах и социиально обусловленной заболеваемости населения Винницкой области, их основных причин и возможностей улучшения cuтуации.

Материаль и методы исследования. Использованы методы исследования: библиосемантичний, системного анализа, ретроспективного анализа здоровья населения в динамике по демографическим показателям; заболеваемости по отдельным классам болезней; медицинской статистики.

Результатьл. В последние годы в Украине ухудшается проблема депопуляции - неуклонного сокращуения населения. Основным фактором формирования демографических прочессов является общественное здоровье, от его уровня в значительной степени зависит развитие таких процессов, как смертность и рождаемость, а также продолжительность предстоящей жизни. Таким образом, здоровье нации определяет численность и качество человеческих ресурсов не только в настоящем, но и в будущем. $B$ статье освещуены основные проблемы формирования народонаселения Винницкой области Украинь: интенсификациия смертности, смертность мужчин, отрицательный естественный прирост, снижение суммарного коэффициента рождаемости, высокий уровень демографической старости. Численность населения Винницкой области уменьшилось за годы независимости на 16,9\% (Украина - на 18,1%). Общий коэффициент рождаемости снизился на 30,9 \%, общий коэффицчиент смертности повысился на 33,0 \%, что привело к негативному естественного прироста и депопуляции. Основными причинами смерти в 2019 году. Стали болезни органов кровообращуения - 67,8 \%; новообразования - 14,6 \%; травмы, отравления и другие последствия внешних факторов - 5,7\%. Несмотря на снижение показателя смертности детей до 1 года в 2 раза, численность детского населения в области уменьшилась более чем на 100 тыс. человек. Население пожилого возраста увеличилось до 300 \%о, что привело к регрессивному типу возрастной структуры. Средняя ожидаемая продолжительность жизни значительно отстает (на 10 и более лет) от стран Западной Европь. Представлень предложения о возможностях улучшения демографической ситуации и профилактики заболеваний, приводящих к наибольиему числу смертей.

Bыводы и перспективы. Оченивая реальные возможности развития человеческого потенцииала в будущуем на примере Винницкой области, можно увидеть, что значительное ухудшение всех основных медико-демографических показателей, которое произоило за последние годы ставит значительные ограничения достаточности человеческих ресурсов для дальнейшего устойчивого развития области и Украины в иелом. Демографические показатели народонаселения Украинь свидетельствуют о глубоком демографическом кризисе, в результате которой численность населения за годы независимости уменьшилась на 9700000 человек, в Винницккой области - на 667 mыс. Есть цүельй ряд объективных предпосылок для дальнейшей 
Єрмішев О. В., Бацилєва О. В., Шумігай І. В., Кученко Т. А.

депопуляции, омоложения показателей смертности от большинства болезней, высокого уровня демографической старости и тому подобное. Необходимо разработать новую долгосрочную целевую комплексную межстраслевую программу "Здоровье начии", основным разделом которой должны стать меры по преодолению демографического кризиса, которые бы охватывали не только вопросы простого воспроизводства населения, но и его развития в иироком социильном контексте. В цүелевую программу должны быть включены цуели устойчивого развития ООН (ЦУР) и обеспечен контроль за их выполнением на выстем уровне.

Ключевые слова: снижение рождаемости, рост смертности, отрицательный естественный прирост, демографическое старение

\section{HUMAN POTENTIAL OF THE REGION: PROBLEMS OF REPRODUCTION, PRESERVATION AND USE IN THE CONTEXT OF SUSTAINABLE DEVELOPMENT \\ O. V. Yermishev, O. V. Batsylyeva, I. V. Shumihai, T. A. Kuchenko}

Abstract. Introduction. Human capital is one of the components of national wealth, therefore, its development should be considered as a factor for strengthening the stability of the territory in the formation of regional policy. The authors' analysis shows that the trends in the development of the human capital lead to a decrease in the stability of the region indicated by the aging population, reduced quality of labour potential, the development of negative migration processes and especially its intellectual characteristics and health capital.

As the world practice shows, ensuring sustainable development of a region and a country as a whole is not possible without increasing human capital and its potential. Its importance in the modernization of all aspects of public life is growing steadily. According to the World Bank, in developed countries $64 \%$ of the structure of national wealth belongs to human capital, $16 \%$ to physical one and only $20 \%$ to raw materials.

In this regard, the human capital and its potential are among the key factors in the transition to an innovative type of development of a region and a country as a whole.

Purpose - to identify patterns of changes and trends in demographic processes and socially determined morbidity of the population of the industrial region of Ukraine, their main causes and opportunities to improve the situation

Materials and methods. The materials of the study were domestic and world scientific sources, annual collections of statistical data of the Dnipropetrovsk region and Ukraine as a whole from the demographic development and morbidity of the population; annual reports of the country's leadership and the Ministry of Health on these issues, information from the WHO Regional Office; legislative documents. Methods were used: bibliosemantic, system analysis, retrospective analysis of public health over demographic indicators (fertility, mortality, natural increase, average life expectancy, child mortality) morbidity for individual classes of diseases leading to the largest share of deaths; medical statistics: relative values, time series, assessment of 
Єрмішев О. В., Бацилєва О. В., Шумігай І. В., Кученко Т. А.

trends in demographic indicators, morbidity, graphic representation of statistical data, computer technologies

Results. The development of the human capital of the population, the quantitative and qualitative potential of its reproduction is a condition, a basis and a goal of sustainable development of society and the state. State policy in the field of public life should be focused primarily on solving the most pressing, priority tasks. In recent years, Ukraine has had a problem of depopulation - a steady decline in population. Public health is the main factor in the formation of demographic processes. Moreover, its level largely affects the development of such processes as mortality and fertility as well as future life expectancy. Thus, the health of the nation determines the number and quality of human resources not only today but also in the future. The population, having a certain life and work potential, loses it at every stage of the development of generations due to injuries, diseases, abortion, stillbirth, premature mortality and so on.

The article highlights the main problems of the formation of the population of the Dnipropetrovsk region of Ukraine: the intensification of mortality, male mortality, negative natural growth, a decrease in the total fertility rate, high levels of demographic aging. The population of the Vinnytsia region has decreased over the years of independence by $16.9 \%$ (Ukraine - by 18.1\%). The overall fertility rate decreased by $30.9 \%$, the overall mortality rate increased by 33.0\%, which resulted in negative natural growth and depopulation. The main causes of death in 2019 were diseases of the circulatory system - 67.8\%; neoplasms - 14.6\%; injuries, poisoning and other consequences of external factors $-5.7 \%$. Despite the decrease in the death rate of children under 1 year by 2 times, the number of children in the region has decreased by more than 100 thousand. people. The elderly population increased to 300 ppm, which led to a regressive type of age structure. Average life expectancy lags far behind (by 10 or more years) from the countries of Western Europe. Proposals are presented on how to improve the demographic situation and prevent diseases leading to the greatest number of deaths.

Conclusions. While assessing the real opportunities for human development in the future taking Vinnytsia region as an example, we can see that the significant deterioration of all major medical and demographic indicators that has occurred in recent years puts significant limitations on human resources for further sustainable development of the region and Ukraine.

Demographic indicators of the population of Ukraine indicate a deep demographic crisis, as a result of which the population has decreased by $9,7 \mathrm{mln}$. people over the years of independence, in the Vinnytsia region - by 667 thousand. There are a number of objective prerequisites for further depopulation, rejuvenation of death rates from most diseases, high levels demographic old age etc. It is necessary to develop a new long-term targeted comprehensive intersectoral program "Health of the Nation", the main section of which should be measures to overcome the demographic crisis, which would cover not only the issues of simple reproduction of the population, but also its development in a broad social context. The target program should include the UN Sustainable Development Goals (SDGs) and monitor their implementation at the highest level. 
Срмішев О. В., Бацилєва О. В., Шумігай І. В., Кученко Т. А.

Key words: decrease in birth rate, increase in mortality, negative natural increase, demographic aging 